\title{
分散形電力貯蔵装置の系統復旧時に 効果的な配置と運用法
}

$$
\begin{array}{lllll}
\text { 正員 奈 良 宏 } & \text { (北見工大) } \\
\text { 正員 山 城 } & \text { 迪 (北見工大) }
\end{array}
$$

\section{1. まえがき}

現在，電力䠉蔵装置としては揚水発電所が唯一実用 に供されているが，更に效率汃良いがるいは立地点 に制約を受けない二次電池などの新形電力眝蔵装置が 開発されつつある(1) (3)。

負荷率向上の目的で電力詝藏装置を設置する場合, 送電損失や経济㛗などの観点から，系統の負荷端䎲分 散配置する方が良いとされている(4),(5)。その場合， 大容量発電所または上位系緒の事故によって電力眝蔵 装置を有する舟線汃得電したとしても，自励式インバ 一夕を用いて貯蔵電力を放電するととによって負苩へ の無停電供給が可能である ${ }^{(6)}$ 。

以上の上うな背景加ら，本論文では電力貯藏装置が 系統の負荷端に分散配置された場合の事故復旧時にお ける効果を停電損失 ${ }^{(7)}$ の観点から検討するための二種 類のアルゴリズムを提案する。第一は，期待婷電損失 を最小にする電力貯蔵装置の配置を求めるものであ る。電力詝蔵装置の配置は前述の経済性の他, 安定度, 信頼度，運用の柔軟性などの条件を考慮して総合的判 断加ら決定され朴ばならない。提案する手法は停電時 の運用の観点加ら配置を求り，経済性以外の条 件をす考虑して配置を決定する場合の重要な手掛りと なるすのの一つである。第二は，与えられた電力眝蔵 装置の配置のもとで個別の停電が発生した場合に，利 用可能眝蔵電力を栲慮に入れて期待停電揖失を最小に する負荷復旧㮌序を決定するむのである。とのような 手法として線形計画法安用いた手法 ${ }^{(7)}$ があるが，負荷 パターンを考虑すると不連続(非線形)制約が加方るた ぬ，これを利用できない。本論文ではこの問題を 0-1 計面問題として定式化し，分枝限定法を用いて解く。 以下，第 2 章では全体の檢討に用いた前提条件を述

Effective Arrangenent and Operation of Dispersed Energy Storage Devices in Power Systems Restoration State. By Koichi Nara, Member \& Susumu Yamashiro, Member (Kitami Institute of Technology)

系良宏一; 正員, 北見工掌大学工学部笔気工学科 山城 迪: 正員, 北見工学工学部籍兴工学科

昭 $60-11$

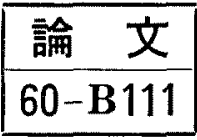

ベ，第 3 章では電力眝藏装置の最適配睓手法，第 4 章 では眝藏電力を考慮に入れた最適負荷復旧順序決定手 法についてその定式化，解法，数值例を示している。 また，数值例の結果から電力眝蔵装置の復旧時におり る効果就よ゙配置の方針について考察を加えている。

\section{2. 前提条件}

〈2・1〉仮定本諭文を通じて以下の仮定をむく。

（1）咛蔵装置を有する変電所 (母線) が停電した

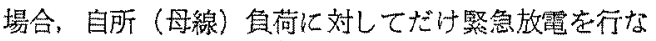

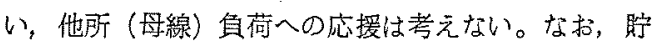
蔵装監加配電用变電所に設備され，他变露所への連絡 線がある場合には，他所解荷の充電を防ぐため，眝藏 電力放電前に速絡線遮新器または变圧器二次 (一次) 側遮断器を開放するすのとする。

（2）貯蔵装置全体亡しての定格貯蔵容量, 定格出 力, 日運用計画汸，負荷率改善のための鼠通運用計画 から既知じある(1)（4)。

（3）変電所ごとにフィーダ単位の日負荷曲線, 停 電発生確率，平均停電復旧時間 $\left(1 / \mu_{i}\right)$ を既知とし，変

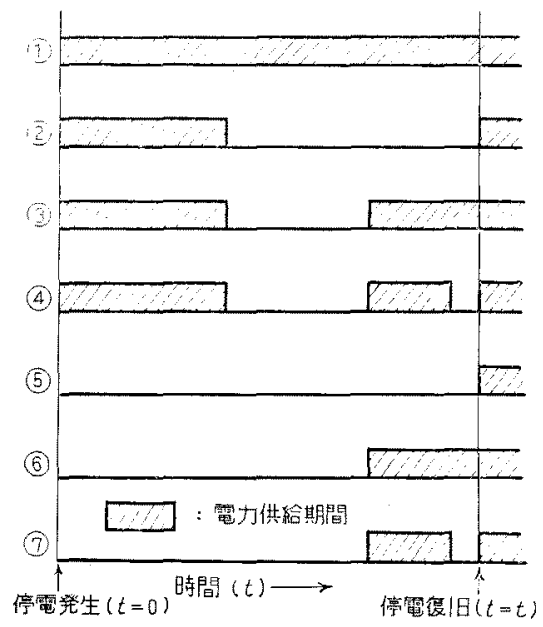

図 1 一回の事故に上る停電の断続パターン

Fig. 1. Black-out patterns by a fault. 


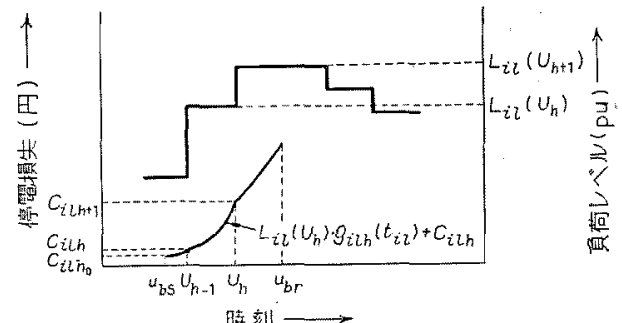

国 2 停電損先曲線

Fig. 2. Electrical power interruption cost.

電所 $i$ の停電継続時間 $t \sim t+\Delta t$ 間の復旧確率は

$$
\begin{aligned}
p_{i}(t, t+\Delta t) & =P_{i}(t)-P_{i}(t+\Delta t) \\
& =\mu_{i} e^{-\mu_{j} t} \Delta t \quad \ldots \ldots \ldots . .
\end{aligned}
$$

で与えられる(8),(11)。

（4）停電時, 貯蔵電力は方らかじめ決められたフ

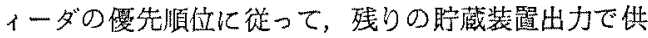
給可能なフィーダが無くなるまで供給される。供給中 の負荷はその大きさが貯蔵装置定格出力を超えるか, または貯蔵電力が無くなったとき，優先順位の低いつ ィーダから腼代供給を停止される。一度停止されたフ ィーダは供給の断続による不快感の增長を避けるため に, 負荷の総量が定格出力以下になり，加残存詝蔵 笔力量で一定時間（本論文では３0分とした）以上供 給可能な場合に限り，一度だけ再供給される。従っ て，一回の事故による停電の継続仕たかだか二回であ り，その起り得るすべての断続パターンを図1亿示す。

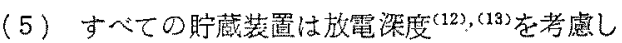

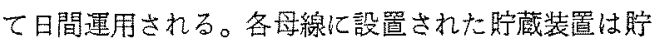
蔵容量化比例した割合で充放電を受持つものとする。 従って，盯蔵装置は次式を満足しなければならない。

$$
\left.\begin{array}{l}
x_{i} \geqq\left(y_{i} / Y_{0}\right) \cdot \operatorname{Max}_{u}\left\{\left|x_{i}{ }^{\prime}(u)\right|\right\} \text { (放䨳時) } \\
x_{i} / \eta_{i} \geqq\left(y_{i} / Y_{0}\right) \cdot \operatorname{Max}_{u}\left\{\left|x_{i}{ }^{\prime}(u)\right|\right\} \text { (充電時) }
\end{array}\right\}
$$

但し， $x_{i}$ : 母線 $i$ の詝藏装置の定格出力, $y_{i}$ : 母線 $i$ の詝藏装置の定格䝪藏容悬, $Y_{0}$ : 全体設供の咛藏容量, $\eta_{i}$ : 母線 $i$ の貯蔵装置 の効率， $x_{i}{ }^{\prime}(u)$ : 母線 $i$ の眝蔵装置の時刻 $u$

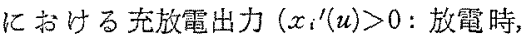
$x_{i}{ }^{\prime}(u)<0:$ 充電時 $)$

$\langle 2 \cdot 2\rangle$ 停霞損失 停電强失に関する多くの調查 報告加ら，停電損失は一般汇停電継続時間 $t$ の二次式 で近似でき，時間帯による停電損失の变動は二次式の 係数を変元ることで対䏎できるとして良い(7)。従っ $\tau$ ，時刻 $u_{b}$ に停電した母線 $i$ フィーダ $l$ の第 $h$ 時
間带 $\left(U_{h-1} \sim U_{h}\right)$ の停電捍失は次式で定義できる。

$$
\begin{gathered}
f_{i l u_{b s}}\left(L_{i l}(u), t_{i l}\right)=L_{i l}(u)\left(a_{i l h} t_{i} l^{2}+b_{i l h} t_{i l}\right) \\
\quad+c_{i l h}=L_{i l}(u) \cdot g_{i l h}\left(t_{i l}\right)+c_{i l h} \quad \ldots \ldots(3)
\end{gathered}
$$

但L, $g_{i i h}\left(t_{i n}\right)=a_{i n h} t_{i l^{2}}+b_{i n h} t_{i !}$

$L_{i l}(u)$ : 時刻 $u$ 飞おける負荷の大きさ， $t_{i l}$ ：

母楾 $i$, フィーダ $l$ 停電継続時間

また，時間带の境界における停電損失は不逨続にはな らないから，図2を参照して，cinは，

$$
\left.\begin{array}{rl}
c_{i l h_{0}}= & L_{i l}\left(U_{h_{0}}\right) c^{\prime}{ }_{i l h_{0}} \\
c_{i l h}= & L_{i l}\left(U_{h-1}\right) g_{i l(h-1)}\left(u_{h}\right) \\
& \left.-L_{i l}\left(U_{h}\right) g_{i l h}\left(u_{h}\right)+c_{i l(h-1}\right)
\end{array}\right\}
$$

但L, $u_{h}=U_{b-1}-u_{b s}, u_{b s}$ : 停電発生時刻,

$c^{\prime}{ }_{i h_{0}}$ : 停電発生時の $\mathrm{kW}$ あたりの固定損

失, $h_{0}$ : 停電が発生した時䦰带

を満足しなければならない。

フィーダごと，時間帯どとに(3)式の倸数 $a_{i \downarrow h}, b_{i \downarrow h}$, $c_{l_{e h}}$ の正確埴值得ると之は多少難加しいかむしれな いが，調查対象がフィーダ単位であり対象負荷が限定 されるため，例えば，文献 (14)，(15) の調查結果のよ う利用可能な程度の情報（相対的な停電損失の伯か わかれば良い)を得ることは可能であるう。

(3)，(4)式加ら，電力眝蔵装置加設置された母線 $i$ で時刻 $u_{b}$ 江発生した一回の事故に扔ける停電継続 時間 $t$ までの停電損失は次式で与えられる。

$$
\begin{aligned}
& f_{i u_{b s} s}\left(t, x_{i}, y_{i}\right)=\sum_{l \in L_{0}} f_{i l u_{b s}}\left(L_{i l}(u), t_{i l}\right) \\
& \quad+\sum_{l} f_{i l u_{s s}}\left(L_{i l}(u), t_{i l^{\prime}}\right) \ldots \ldots \ldots \ldots \ldots(5) \ldots \ldots . . .
\end{aligned}
$$

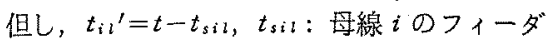

$l$ 名停電㣪, 一旦貯蔵装置上り電力供給を受

け，その後再停電するまでの時間， $L_{0}=\{l] t$

$=0$ で䠉蔵装置加ら供給可能なフィーダ】

（5）式の右辺の第 1 項は一度目の停雪，第 2 項は二 度目の停電の停電損失を表している。なお，停電の一 度目と二度目で停雪損失が変るなら占，(3)式の係数 をそれに応じて変えることで詨処できる。

$\langle 2 \cdot 3\rangle$ 電力貯藏装置の運転特性 電力眝蔵装置 設置変電所母線が停電した場合には，日間運用に関保 なく眝蔵電力を婜急放電する。婜急時の放電樑度は常 時と同じかそれより大きくとれるものとする。さて， 時刻 $u_{s}$ 加ら時刻 $u_{e}$ まで日間運用した場合の時刻 致に括ける残存眝蔵容量位次式で与えられる。

$$
\begin{aligned}
y_{i r s}\left(u_{e}\right)= & \int_{u \subseteq U_{d}} x_{i}{ }^{\prime}(u) d u+\eta_{i} \int_{u \subseteq U_{0}} x_{i}{ }^{\prime}(u) d u \\
& +y_{i r s}\left(u_{s}\right) \quad \ldots \ldots \ldots \ldots \ldots \ldots \ldots(6)
\end{aligned}
$$

但し， $y_{i r s}(u)$ : 時刻 $u$ における残存眝藏容量， 
$U_{d}: u_{s} \sim u_{e}$ 閪のうち放電している時間帯,

$U_{c}: u_{s} \sim u_{e}$ 間のうち充電している時間組

また，館藏装置の充電電力量と放䉓電力配が等しけれ

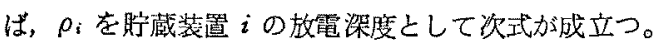

$$
\int_{u \subseteq U_{d}} x_{i}^{\prime}(u) d u=-\eta_{i} \int_{u \subseteq U_{\varepsilon}} x_{i}^{\prime}(u) d u \leqq \rho_{i} y_{i}
$$

一方, 停電中または停電復旧㭙の残存眝蔵容量 $y_{i}$ は,

$$
y_{i r}=y_{i r s}\left(u_{b s}\right)+\int_{u_{b s}}^{u_{b r}} w_{i}(u) d u
$$

但し,

$$
w_{i}(u)=\sum_{i \in L_{u}} L_{i l}(u)
$$

$u_{b s}$ : 停電発生時刻, $u_{t r}$ : 停電復旧㭙刻, $L_{u}$ :

時刻いに放いて眝蔵装置より供給中のフィー ダ番号の集合

\section{として計算される。}

$\langle 2.4\rangle$ 発霓機出力上界特性 時刻 $t_{0}$ ○発電耭出 力 $P_{\theta}\left(t_{\theta}\right)$ は折れ線で与えられ，次式で表わす(7)。

$$
P_{\theta}\left(t_{0}\right)=d_{q}\left(t_{\theta}-t_{\theta 1}\right)+e_{q}
$$

ここで $d_{0}$ は発電機出力の上昇しう配 $\left(t_{0}<t_{01}, t_{0}>t_{02}\right.$ で $\left.d_{\theta}=0\right), t_{0}$ は発電僟 $g$ 力゙脱落してからの相対時咕 $\left(t_{g}=0\right.$ で発電機 $g$ が脱落)， $t_{g 1}$ は発電機 $g$ が脱眥後 目荷をとるまでの時間， $t_{g 2}$ は発電機 $g$ が脱落後再び 真荷をとり，定格出力に至るまでの時間である。

\section{3. 停電損失最小化を目的とした電力貯蔵装 置の最適配置手法}

\section{〈3.1〉 問題の記述}

（1）電力眝蔵装置の最適配置問題 期待停電損 失最小を目的とする電力眝藏装置配監問題は以下のよ うに記述できる。

〔目的関数〕

$$
F_{T}=\sum_{m=1}^{M} B_{m}\left(F_{L m}+F_{P m}\right) \rightarrow \text { 最小...... }
$$

但し, $F_{T}$ : ペナルティを含めた総期待停電提 失, $F_{L m}$ : 事故ケース $m$ の全停電期間にわた る期待停電損失， $F_{P m}$ ：停電事故ケース $m$ の 眝蔵電力消費による負荷率恶化に対するぺ ナルティ， $B_{m}$ : 亭故ケース $m$ の重み係数 $\left(\sum_{m=1}^{M} B_{m}=1\right), M$ : 考察する專故ケースの数

【制約条件〕

貯蔵容量制約: $\Sigma_{1} y_{i} \leqq W H_{0}$ (全体設菕) $y_{00} \leqq y_{i} \leqq y_{0 i}$ (個別設嚾)

定格出力制約 : $\Sigma_{i} x_{i} \leqq W_{0}$ (全体設備) $x_{00} \leqq x_{i} \leqq x_{0 i}$ (個別設满)
最小供給可能時闍制約 : $y_{i} / x_{i} \geq T_{0 i}$

但し， $y_{i}, y_{0 i}, y_{00}:$ 母線 $i$ 亿設置される眝蔵 装置の眝蔵容曨およびその上限，下限， $x_{i}$,

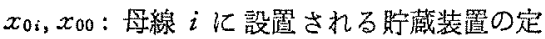
格出力およびその上限，下限，Wo, WHo:全 体設储について合部した定格出力および眝藍 容量の上限倠， $T_{0 i}$ : 舟線 $i$ 亿設置される眝 蔵装置の最小供給可能繼続時間

（2）期待停電損失の計算 (11) 式の $F_{L m}$ は全 变䨩所の期待停電損失の和であり次式で計算される。

$$
\begin{aligned}
& F_{L m}=\sum_{i} F_{i m} \quad \ldots \ldots \ldots \ldots \\
& F_{i m}=\int_{u_{s}}^{u_{\ominus}} A_{i m m} \cdot F_{i u m} d u
\end{aligned}
$$

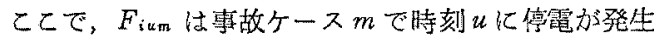
した韵合の変電所 $i$ の期待停電損失, $A_{i u m}$ は事故ケ 一ス $m$ の時刻 $u$ におりる停霘発生確率または重少係 数で $\int_{u_{s}}^{u_{e}} A_{i u m} d u=1$ である。优って， $F_{i m}$ は全考察期 間にわたる整故尔一ス $m$ における变電所 $i$ の期待停 電損失である。 $F_{i m m}$ は， $f_{i u m}\left(t, x_{i}, y_{i}\right)$ 专故ケース $m$ にお河 (5)式の值しして，次式で与えられる。

$$
F_{i u m}=\int_{0}^{\infty} p_{i}(t) f_{i u m}\left(t, x_{i}, y_{i}\right) d t
$$

（3）負荷率改善効果減少に対するペナルティ 停電による放電または充電不足によるピーク時不足電 力にペナルティを与え，停電損失の減少上発電原価の 上开との協調をとることが考えられる。通常停電継続

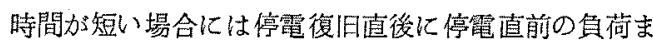
で立上ると仮定して良く，逆仪長い場合には後述する ようにペナルティが停電提失と比較して無視できるほ よ゙小さいので, 停霓復旧直後に計雨通りの真荷をと り，また，充放電を行なうものと仮定すると，停電に よるピーク時の不足電才量は，次式で部算される。

$$
P_{d i}=H_{i p}-y_{i r}\left(P_{d i}=0 \text { if } P_{d i}<0\right)
$$

但L。

$$
H_{i p}=\int_{v_{p s}}^{v_{p e}} x_{i}{ }^{\prime}(u) d u
$$

$P_{d i}:$ ピ一ク眭の不足電力量, $v_{p s}, v_{p e}$ ：停電

復旧後の放霎開始および䅂了時刻 この不足電力量は予備力起動などで補うので，運軾䩀 と固定費とを考感してペナルティを次式で定義する。

$$
F_{p}=a_{p}\left(\sum_{i=1}^{N} P_{d i}\right)+b_{p}
$$

ここで， $a_{p}, b_{p}$ は定数， $N$ は変電所数である。

$\langle 3 \cdot 2\rangle$ 問題の解法 (11) (14) 式の問題は, (11) 


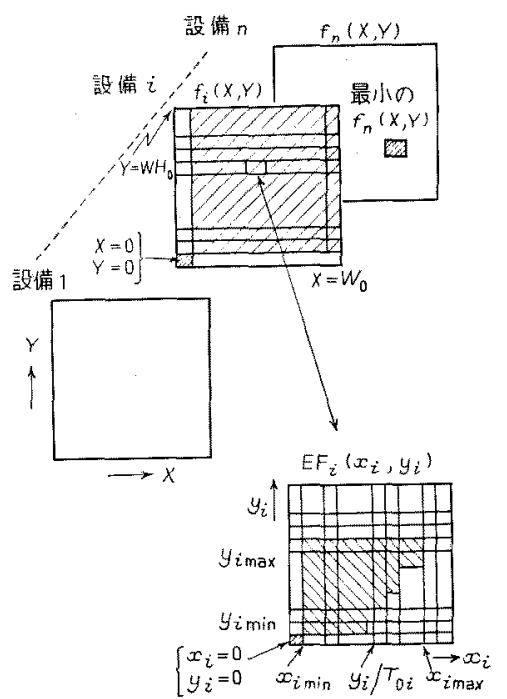

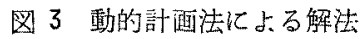

Fig. 3. Solution method by DP.

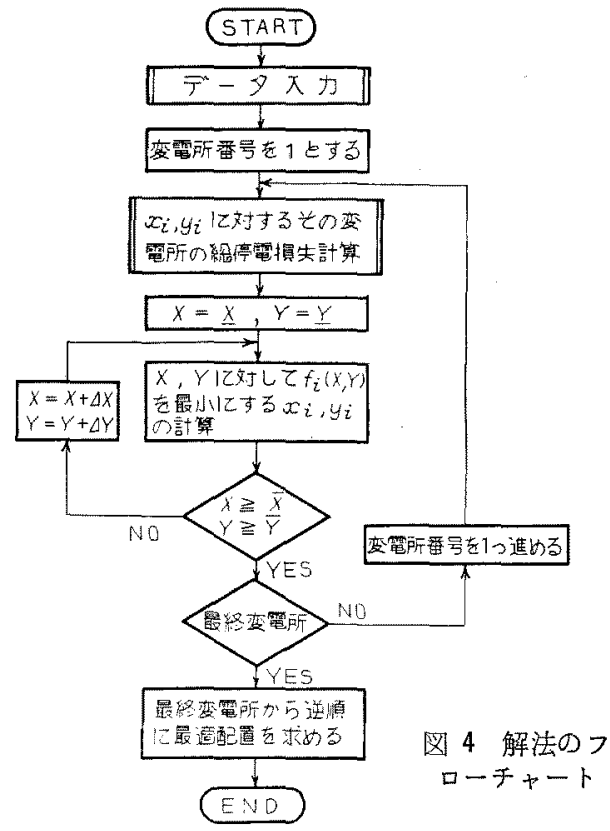

Fig. 4. Flowchart for the solution.

式が非線形のため非線形計面問題として解く必要があ る。本覦文では，ステップに变電所番号をとり，第 $i$ ステップにおいて

$$
X=\sum_{k=1}^{i} x_{k}, \quad Y=\sum_{k=1}^{i} y_{k}
$$

とおいて動的計画問題として解く。いま，变電所 $i の$ 期待停電損失它 $E F_{i}\left(x_{i}, y_{i}\right)$, 変電所 1 加 ら変電所 $i$
までの罢䅠期待停電損失を $f_{i}(X, Y)$ として溸化式を 作ると次のようになる。

$$
\begin{aligned}
f_{i}(X, Y)= & \operatorname{Min}_{x_{i}, y_{i}}\left[E F_{i}\left(x_{i}, y_{i}\right)\right. \\
& \left.+f_{i-1}\left(X-x_{i}, Y-y_{i}\right)\right] \ldots
\end{aligned}
$$

但し， (12) (14) 式の制約加ら,

$$
\left.\begin{array}{l}
f_{0}(X, Y)=0 \\
\operatorname{Min}\left(X, x_{0 i}\right) \geqq x_{i} \geqq x_{00} \\
\operatorname{Min}\left(Y, y_{0 i}\right) \geqq y_{i} \geqq \operatorname{Max}\left(x_{i} \cdot T_{0 i}, y_{00}\right)
\end{array}\right\}
$$

が満足されね标らない。しの制約下で， $\Delta X, \Delta Y$ を 增設の最小䇲位として，i=N のときの(21)式の值を 最小にする各ステップの $x_{i}, y_{i}$ の値を四3に示すよ うに順次ステップ苦進めて求めていりば良い。な格， $X=0$ 加つ $Y>0$ または $X>0$ かつ $Y=0$ のケース は起り得ない。全体の解法它図4亿示す。

〈3.3〉数值例 まず，一般的な傾向を見るため， 負荷を一定 (1.0 p.u.) とし，停電挰失 $\left(f_{i} u_{b s}=a_{i} t_{i}{ }^{2}\right.$;
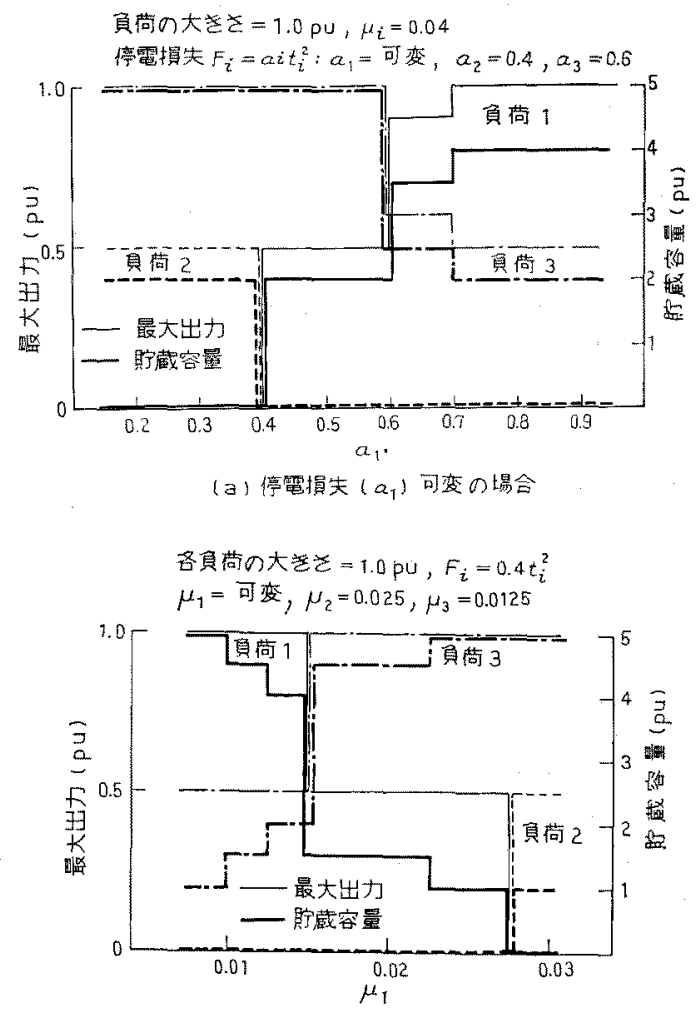

(b) 平䏛儚電継続䁌間 $\left(\mu_{1}\right)$ 可变の場合

図 5 停電損失之平均停電継続時間による 貯藏装置の配置の変化

Fig. 5. Power storage arrangement depending on the cost and the duration of electrical power interruption. 
ペナルティ無視) の二次項の係数 $a_{i}$ 並じに(1)式の $\mu_{i}$ をパラメータとして(11)〜(14)式を解くと，図 5 (a)，(b)の上うな結果汃得られる(8)。四5 加ら，他 の条件が同じであれば，その時間帯の停電損失が大き
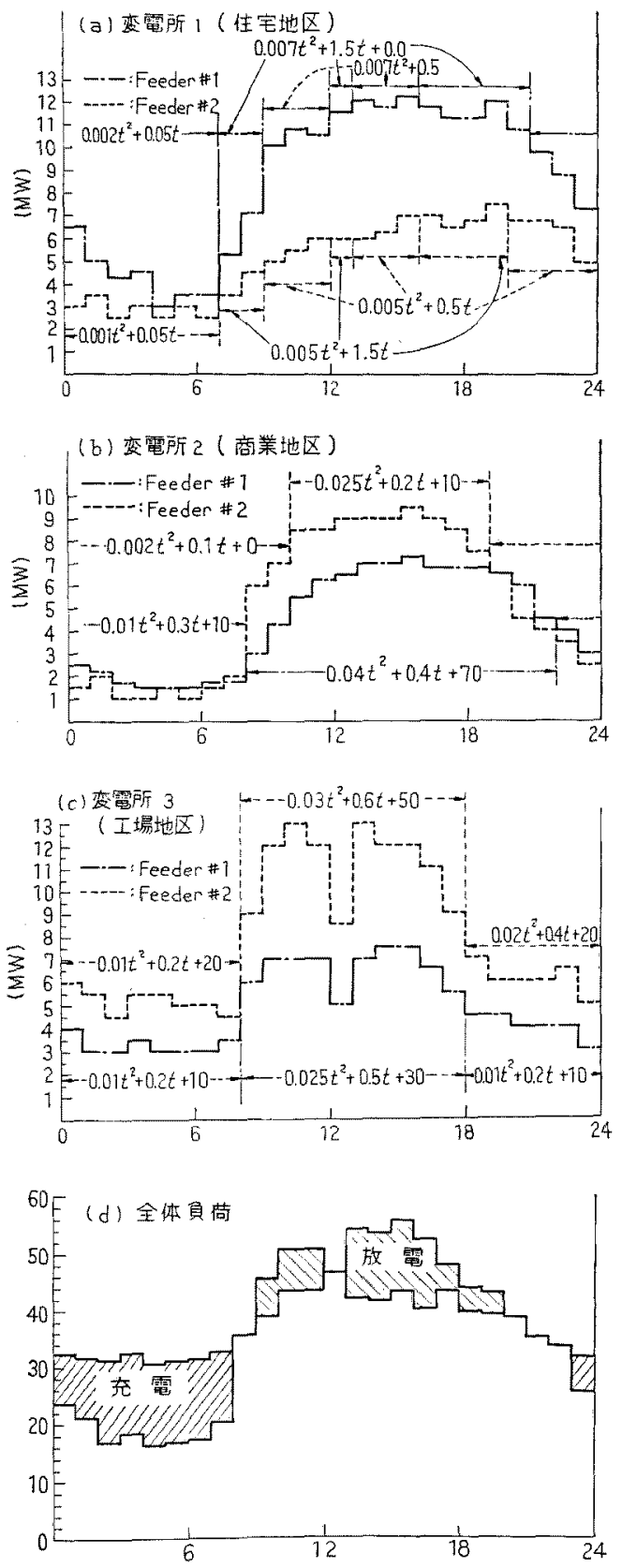

図 6 数值例 10 日目荷曲線（ $t$ の二次式は渟電 損失曲線：单位 $10^{5} \mathrm{~m} / 10 \mathrm{MW}$ )

Fig. 6. Daily load curve for numerical example (1).
い負荷または平均停電継続時間の長い負荷ほど大容量 の眝蔵装置を設備した方が良いことがわかる。

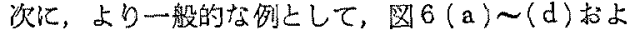
び表 1 に示すような，フィーダ各 2 本を持つ 3 変雷所 へ電力貯蔵装置を配置する場合を考える。考察中の全 変電所が停電に至る事故ケースだけを取报って得られ た結果の一部志図7，図8，表 2 ，表 3 亿示す。図7 並びに表 2 は停電発生時刻に関して一日の停電損失の 期待値（本例題では 毎時 30 分に停電が等しい確率で 発生すると仮定して平均をとった）をとった場合の結

\section{表 1 例题の定数}

Table 1. Constants for the example.

$x_{00}=0.2, \quad x_{0 i}=4.0, \quad W_{0}=4.0 \quad$ [P.U. $y_{60}=1.0, \quad y_{0 i}=16.0, \quad W H_{0}=16.0 \quad$ [P.U.] $a_{p}=5.0, b_{p}=0.0 \quad\left[\times 10^{5} \mathrm{M} / \mathrm{P}\right.$. U. $]$

$\mu_{1}=\mu_{i}=\mu_{3}=0.04, \quad y_{i} / x_{i} \geq 0.5, \quad$ I P. U. $=10 \mathrm{MW}$

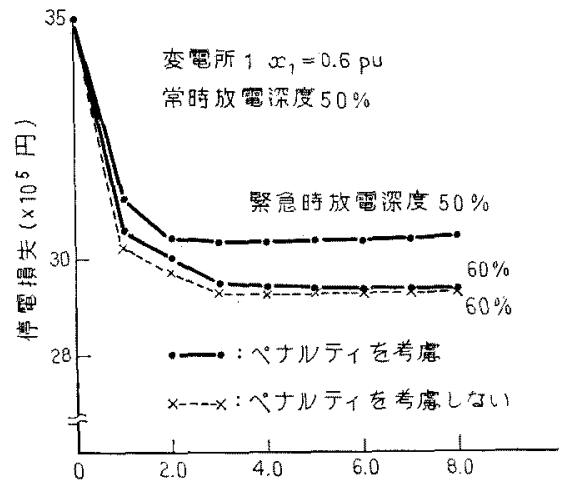

图 7 聍蔵容量と停電損失の関係 （停電発生時刻红関吉方期待值）

Fig. 7. Relationship between power storage capacity and electrical power interruption cost.

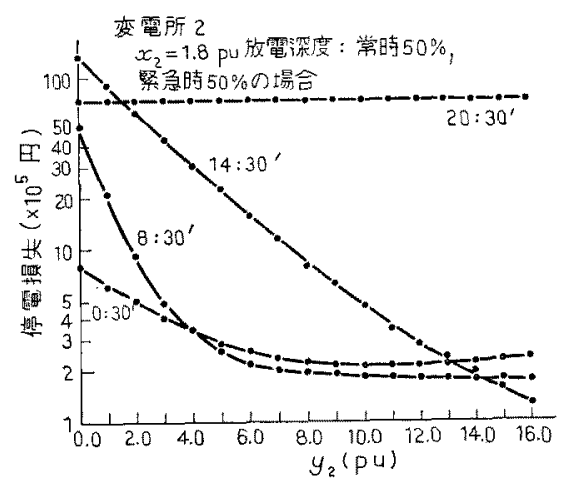

図 8 貯藍容量之停電損失の関係(停電発生時刻別)

Fig. 8. Relationship between power storage capacity and electrical power interruption cost. 
果である。表 2 の配置は，特定の㭙刻化停電が発生す ると仮定して求めた表 3 のいずれの配置とも一致しな いが，停電発生時刻に関して平均的な効果が期待でき る。図7 は眝蔵容量代刘する停電損失の傾向を示した むのである。眝蔵容量の增加化う停電損失の減少は 負荷パターンや平均停電継続時間など，系統の特性か

\section{表 2 放電深度に対する最適配置}

(停電発生時刻江関する期待値)

Table 2. Optimum storage facility arrangement for different discharge depth.

\begin{tabular}{|c|c|c|c|c|}
\hline 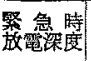 & S/S 名 & 定格出力 & 眝藏容琶 & 停婯損失 \\
\hline \multirow{4}{*}{$50 \%$} & $S / S 1$ & $1.2^{(\text {P. U. })}$ & 4. (P.U.) & 20.71 \\
\hline & $\mathrm{S} / \mathrm{S} 2$ & 0.8 & 4.0 & 29.76 \\
\hline & S/S 3 & 2.0 & 8.0 & 16.76 \\
\hline & 合 愺 & 4.0 & 16.0 & 67.23 \\
\hline \multirow{4}{*}{$55 \%$} & $\mathrm{~S} / \mathrm{S} 1$ & ${ }_{1 .}^{(\text {P. U. })}$ & $4_{4 .}^{(\mathrm{P} . \mathrm{U} .)}$ & $17.23^{\left(\times 10^{5} 円\right)}$ \\
\hline & $S / S 2$ & 0.8 & 5.0 & 19.86 \\
\hline & S/S 3 & 2.0 & 7.0 & 8.49 \\
\hline & 含 柿 & 4.0 & 16.0 & 45.570 \\
\hline \multirow{4}{*}{$60 \%$} & $\mathrm{~S} / \mathrm{S} 1$ & $1.2^{(\mathrm{P} . U .)}$ & ${ }_{4.0}^{(\mathrm{P} . \mathrm{U} .)}$ & 15.01 \\
\hline & $\mathrm{S} / \mathrm{s} 2$ & 0.8 & 4.0 & 18.06 \\
\hline & S/S 3 & 2.0 & 8.0 & 3.00 \\
\hline & 合 計 & 4.0 & 16.0 & 36.07 \\
\hline \multirow{4}{*}{$65 \%$} & $\mathrm{~S} / \mathrm{S} 1$ & $1.2^{(\mathrm{P} . \mathrm{U} .)}$ & $4.0^{(P . U .)}$ & $\begin{array}{l}\left(\times 10^{5} \mathrm{P}\right) \\
13.65\end{array}$ \\
\hline & $\mathrm{S} / \mathrm{S} 2$ & 0.8 & 4.0 & 16.72 \\
\hline & $\mathrm{s} / \mathrm{S} 3$ & 2.0 & 8.0 & 1. 33 \\
\hline & 合 壾 & 4.0 & 16.0 & 31.70 \\
\hline
\end{tabular}

表 3 停電発生時刻ごとの最適配置

Table 3. Optimum storage facility arrangement for different fault occurrence time.

\begin{tabular}{|c|c|c|c|c|}
\hline 竳生時刻 & S/S 名 & 定格出力 & 眝葴容骴 & 停笔損失 \\
\hline \multirow{4}{*}{0 时 30 分 } & $S / S I$ & $1.0^{(\mathrm{P}, \mathrm{U} .)}$ & $4.0^{(\text {P. U. }}$ & $0.6960^{\left(\times 10^{5} \mathrm{f}\right)}$ \\
\hline & $S / S 2$ & 0.6 & 3.0 & 0.335 \\
\hline & S/S 3 & 1.0 & 9.0 & 0.398 \\
\hline & 合 募 & 2.6 & 16.0 & 1.429 \\
\hline \multirow{4}{*}{8 时 30 分 } & $S / S 1$ & $1.2^{(\mathrm{P}, \mathrm{U} .)}$ & $5.0^{(\text {P.U. })}$ & $3.24^{\left(x^{10^{5}} \mathrm{~m}\right)}$ \\
\hline & $s / S 2$ & 0.8 & 2.0 & 6.622 \\
\hline & S/S 3 & 2.0 & 9.0 & 0.476 \\
\hline & 合 副 & 4.0 & 16.0 & 10.312 \\
\hline \multirow{4}{*}{14 封30分 } & S/S 1 & $0.0^{(\mathrm{P}, \mathrm{U})}$ & $0.0^{(P . U .)}$ & $38.953^{\left(\times 10^{5} \mathrm{P}\right)}$ \\
\hline & $S / S 2$ & 1.8 & 7.0 & 2.054 \\
\hline & S/S 3 & 2.0 & 9.0 & 1.510 \\
\hline & 合 計 & 3.8 & 16.0 & 42.517 \\
\hline \multirow{4}{*}{20 懗30分 } & $S / S I$ & 1.8 (P.U.) & 6. (P.U.) $^{(1)}$ & $4.835{ }^{\left(\times 10^{5} \mathrm{~m}\right)}$ \\
\hline & S/S 2 & 0.6 & 5.0 & 2.420 \\
\hline & $s / 53$ & 1.0 & 5.0 & 7.020 \\
\hline & 合 & 2.4 & 16.0 & 14.275 \\
\hline
\end{tabular}

ら決るある大きさ以上の詝蔵容量では期待できない。 この理由は，貯蔵装置定格出力上り負荷の方が大きい 時閭帯には眝蔵電力を負荷に供給できないためであ る(8)。また，緊急時の放電深度が小さい場合には， 大きくとった場合に比へて停電損失の減少は小さい。 更に，図 7 で，緊急洔放電深度が $60 \%$ の場合にピー ク時不足電力に対するペナルティを考慮しない場合の 結果を示しているが，考慮した場合との差は1\% 以下 であり，通常の運用ではこれを無視できる。この理由 は，停電継続時間が短い場合には眝蔵電力の消費が小 さく，従ってペナルティも小さくなり，逆伅停電継続 時間が長ければ，その一次式で計算されるぺナルティ に比較して，その二次式で計算される停電損失の方が 極端に大きくなるととによっている。

一方, 表 3 と図 8 之は停電発生時刻どとの結果定示 している。とれから，停発電生の時間帯によって眝蔵 装置の効果と最適配置が大きく異るととがわかる。と れは，図 5 の傾向並びにその時間帯の負荷の大きさと 設備の定格出力との関係で緊急放電可能星が決るとと などに起因している。また，緊急時の放電深度が変る と, 最邀配置む多少变るが，乙の影響が大きいのは日 間運用の放電終了後の数時間に限られており，一日平 均するとほとんど無視できる。表 $2 て ゙$ 放電泳度による 差が見られないのはこのためである。なお，停電発生 時刻㹥あらかじめ予測できないので，最適配置は前述 の発生時刻関する期待值をこったものとなる。

ところで，表 2 並びに表 3 では，負荷の大きさがほ 浔同じであ机ば停電損失が大きい工場地区に大きな䠉 蔵装置を配置すれば良いという結果になっている。こ 动は，図5の傾向からも明ら加であり，経済性の観点 加ら検討された結果(3)とも一致している。

\section{4. 電力貯蔵設備を持つ系統の最適負荷復旧 順序決定手法}

〈4・1〉問題の記述 前章の方法などにより求め られた最適配置のむとで個別の事故が発生した場合， 停電の状況淿よって, 発電機出力の增加に応じて負荷 をとっていく過程での電力詝藏装置利用の状況む異っ てくる。そのため，その場合の停電損失を最小にする ような負荷復旧順序が決るはずである。この問題は， 負荷を単位量 $\Delta$ の整数倍で表わし，発電機の総增加 出力が $j \Delta$ 亿達する時点を $j$ とすると，次の上うに 0-1 計画問題として定式化できる(10)。

〔目的関数〕

$$
F=\sum_{i=1}^{N} \sum_{j=1}^{N^{\prime}} F_{i j} z_{i j} \rightarrow \text { 最小 }
$$


(a) 变電所 $5 \quad 0.7 t^{2}+6.0 t$
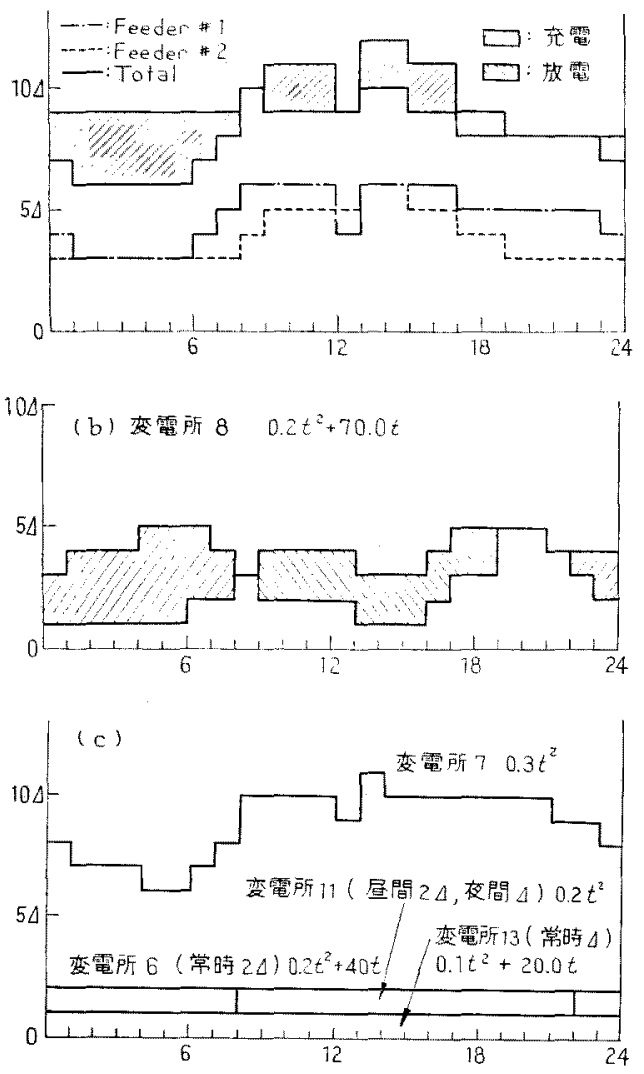

図 9 数值例 20 日頁荷曲線 $(t$ の二次式は $\Delta$ あたりの停電損失曲線：等位 $10^{5}$ 円)

Fig. 9. Daily load curve for numerical example (2).

\section{〔制約条件〕}

$$
\begin{aligned}
& \sum_{j=1}^{N^{\prime}} z_{i j}=1 \quad(i=1,2, \cdots, N) \ldots \ldots \ldots \ldots \ldots(24) \\
& \sum_{i=1}^{N} z_{i j}\left\{\begin{array}{l}
\geqq 1 \text { if } \exists i \in I^{\prime}, I^{\prime}=\left[i \mid k^{\prime} \geqq L_{i j}\right] \\
=0 \text { if } \forall i, k^{\prime}<L_{i j} \\
\left(j=1,2, \cdots, N^{\prime}\right) \ldots \ldots \ldots \ldots .(25)
\end{array}\right.
\end{aligned}
$$

但し，

$$
\begin{aligned}
& k^{\prime}=j-\sum_{i \in I_{j-1}} L_{i j} \ldots . . \\
& I_{j-1}=\left[i \mid \sum_{k=1}^{j-1} z_{i k} \neq 0\right]
\end{aligned}
$$

変数 $z_{i j}$ 付㭙点 $j$ で負荷 $i$ が復旧されたとき 1 ， そ 机以外で0をとる变数である。また， $L_{i j}$ 恃時点 $j に$

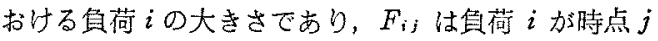
で復旧したときの停電損失である。 $F_{i} ;$ は， $x_{i}, y_{i}$ が 嵁知であり，負荷パターンから停雷中の詝蔵装置の運 用がわかると上扎よび時点 $j$ までの停電継続時間が発

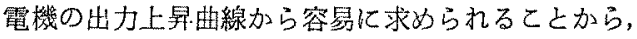

(5)式で直接棓算される。

〈4·2〉問題の解法 (23) 式 (27) 式の問題は (24)，(25) 式の制約のをとで (23) 式老最小にするよう な $z_{i j}=1$ の組合せを求める組合せ間題になってい る。最適性の原理が適用できないので，以下は傊荷 を幅，時点 $j を$ 漂さとする分枝限定解法を用いる。

（1）分枝法 一般に, 考察中の時点加ら全負荷 復旧に至当までの期待停電强失が大きい負荷ほど早く 投入したすが全体の停笪損失を小さくするであるうこ とが予测される。そこで，特点jまでにまだ分枝を試 みていない真荷iについて次式它満足するものを次の

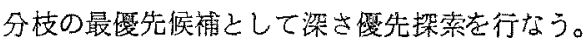

$$
\operatorname{Max}_{i \in I_{j-1}}\left\{F_{i}\right\}=\operatorname{Max}_{i \in I_{j-1}}\left\{\left(\sum_{k=j}^{N^{\prime}} F_{i k}\right) /\left(N^{\prime}-j+1\right)\right\}
$$

\begin{tabular}{|c|c|c|c|c|c|c|c|c|}
\hline \multirow{2}{*}{ 萑晸所名 } & \multicolumn{2}{|c|}{ 平均抢配濫 } & \multicolumn{2}{|c|}{ 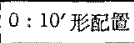 } & \multicolumn{2}{|c|}{$8: 10^{\prime}$ 形㥸睢 } & \multicolumn{2}{|c|}{$16: 10^{\prime}$ 形配濏 } \\
\hline & $\begin{array}{l}\text { 定袺 } \\
\text { 出力 }\end{array}$ & 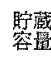 & $\begin{array}{l}\text { 定格 } \\
\text { 出力 }\end{array}$ & 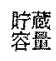 & $\begin{array}{l}\text { 定格 } \\
\text { 出力 }\end{array}$ & 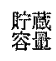 & $\begin{array}{l}\text { 定䇸 } \\
\text { 出力 }\end{array}$ & $\begin{array}{l}\text { 眝藏 } \\
\text { 容基 }\end{array}$ \\
\hline S/S 5 & $3 \Delta$ & 304 & $6 \Delta$ & $60 \Delta$ & $4 \Delta$ & $40 \mathrm{~A}$ & 0 & 0 \\
\hline$S / S 7$ & 0 & 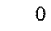 & 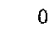 & 0 & 0 & 0 & 0 & 0 \\
\hline $\mathrm{S} / \mathrm{S} 8$ & $4 \Delta$ & $40 \mathrm{~A}$ & $1 \Delta$ & $10 \Delta$ & $3 A$ & $30 \mathrm{~A}$ & $7 \Delta$ & $70 \mathrm{~A}$ \\
\hline
\end{tabular}

\section{表 4 停電発生時ごと刻の最適配置}

\begin{tabular}{|c|c|c|c|c|}
\hline \multirow{2}{*}{ 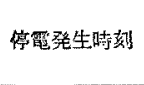 } & 專故 ケ & $-\pi 1$ & 事故ヶ & x 2 \\
\hline & 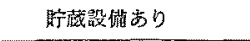 & 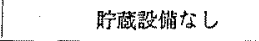 & 剧藏設俑あり & 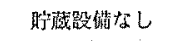 \\
\hline $0: 10^{\prime}$ & $\begin{array}{c}13-11 \rightarrow 6 \rightarrow 5 \rightarrow 7 \rightarrow 8 \\
4,417.2 \text { F円 } \\
\end{array}$ & $\begin{array}{c}8 \rightarrow 6 \rightarrow 5 \rightarrow 13 \rightarrow 7 \rightarrow 11 \\
6.118 .2 \mp 队 3\end{array}$ & $\begin{array}{c}6 \rightarrow 13 \rightarrow 5 \rightarrow 7 \rightarrow 11 \\
4,372.8 \mp F\end{array}$ & $\begin{array}{r}6 \rightarrow 5 \rightarrow 13 \rightarrow ? \rightarrow 11 \\
5,570.4 \text { 干月 }\end{array}$ \\
\hline $8: 10^{\prime}$ & $\begin{array}{c}6 \rightarrow 5 \rightarrow 13 \rightarrow 7 \rightarrow+11 \rightarrow 8 \\
8,907.2\end{array}$ & $\begin{array}{c}8 \rightarrow 6 \rightarrow 5 \rightarrow 7 \rightarrow 13 \rightarrow 11 \\
13,893.1\end{array}$ & $\begin{array}{c}6 \rightarrow 5 \rightarrow 13 \rightarrow 7 \rightarrow 11 \\
9,709.4\end{array}$ & $\begin{array}{c}6 \rightarrow 5 \rightarrow 13 \rightarrow 7 \rightarrow 11 \\
9.709 .4\end{array}$ \\
\hline $16: 10^{\prime}$ & $\begin{array}{c}6 \rightarrow 5 \rightarrow 13 \rightarrow 7 \rightarrow 11 \rightarrow 8 \\
10,446.2\end{array}$ & $\begin{array}{c}8 \rightarrow 6 \rightarrow 5 \rightarrow 7 \rightarrow 13 \rightarrow 11 \\
19,251.2\end{array}$ & $\begin{array}{l}6 \rightarrow 5 \rightarrow 7 \rightarrow 13 \rightarrow 11 \\
11,284.6\end{array}$ & $\begin{array}{c}6-5 \rightarrow 7 \rightarrow 13 \rightarrow 11 \\
11,284.6\end{array}$ \\
\hline
\end{tabular}

Table 4. Optimum power storage arrangement for different fault occurrence time.

表 5 最遮負荷復旧順序と停電損失

Table 5. Optimum load restorative sequence and interruption cost. 
（2）限定法 全負荷復旧までの累積停電損失 は，時点 $j$ までに復旧した負荷の罢積停電損失と，残 りの負荷定時点 $(j+1)$ ですべて投入した場合の停電 損失の和よりは小さくはなり得ない。ゅえに，時点 $j$ までの $q$ 番目の部分解集合 $\Omega_{j}{ }^{q}$ を選択したときの罢積 停電損失の下界值は次式の $E\left(\Omega_{j}{ }^{q}\right)$ で与えられる。

$$
E\left(\Omega_{j}{ }^{q}\right)=f_{j}+\sum_{j \notin I_{j}} F_{i(j+1)}
$$

但L,

$$
f_{j}=\sum_{i=1}^{N} \sum_{k=1}^{j} F_{i k} z_{i k}
$$

また，発電機の運枟限界を超えて運転するととはでき ないので，次式を満足しない分枝は許されない。

$$
k^{\prime}(j) \leqq k^{\prime} \leqq \overline{k^{\prime}(j)} \text {. }
$$

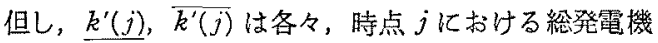
增加出力の下限値亡上限值である。

$\langle 4.3\rangle$ 数值例 上記手法を文献 ( 7)と同一の 30 ノード采統へ適用した。但し，各負荷の日負荷曲線並 び俚時間帯でとの停電損失曲線を必要亡するため，乙 れを図 9(a)〜（c)の上うに与えている。ての柔統に おいて，電力詝蔵装置の設置候補母線番号を， $5,7,8$ として，ての 3 母線を含む停電事故に対して前章の最 適配置手法を適用すると表 4 亿示す解吕得ら九る。乙 の解は，放電深度を常時 $50 \%$ ，緊急時 $65 \%, W_{0}=$ 7.0P.U, $W H_{0}=70.0$ P.U. とし，(21)式のペナルテ 無視して得られたものである。得られた結果の 24 時間平均形配置に対ず盆荷率改善日間運用の充 放電計画を図9に重るて記入しておる。この配置のす とで，文献(7)の事故ヶース $1 ， 2$ に対して本手法を 適用して得られた最適負荷復旧順序とそのときの新積 期待停電損失減少効果を表 5 亿示している。

一方，平均形配置の效果を確認するため，貯蔵装置 の配䈯を変えた場合汇種々の時刻化発生する停電によ る䋜積期待損失の大きさを，眝蔵装置を設置しない場 合の值を 100 として表 6 亿示している。な㧍，表6の 事故ケース2で停電損失減少効果が小さいのは，母線 8が停電に至っていないためである。

\begin{tabular}{|c|c|c|c|c|c|}
\hline & 停 & 平均形配港 & $\begin{array}{l}0: 10^{\prime} \\
\text { 非配置 }\end{array}$ & $8: \frac{10^{\prime}}{\text { 形记漹 }}$ & 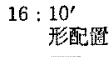 \\
\hline \multirow{3}{*}{$\begin{array}{l}\text { 霖 } \\
\text { 故 } \\
\text { ケ } \\
1 \\
\text { × } 1\end{array}$} & $0: 10^{\prime}$ & 72.2 & 34.5 & 90.2 & 92.2 \\
\hline & $8: 10^{\prime}$ & 64.1 & 75.6 & 50.6 & 64.1 \\
\hline & $16: 10^{\prime}$ & 54.3 & 80.3 & 100.0 & 52.2 \\
\hline \multirow{3}{*}{$\begin{array}{l}\text { 慗 } \\
\text { 故 } \\
1 \\
1 \\
2\end{array}$} & $0: 10^{\prime}$ & 78.5 & 38.6 & 70.9 & 100.0 \\
\hline & $8: 10^{\prime}$ & 100.0 & 69.1 & 79.8 & 100,0 \\
\hline & $16: 10^{\prime}$ & 100.0 & 72.2 & 100,0 & 100.0 \\
\hline
\end{tabular}

表 6 相対的停電挰失

Table 6. Relative interruption cost.

\section{5. 結 論}

電力系統復旧時化分散形電力詝蔵装置を効果的に運 用する手法として，期待停電損失最小を目的とした眝 蔵装置の最適配置と，その配置のもとでの個別事故に 対する最適負荷復旧順序を決定する手法を示した。乙 れらの手法の数值例によって, 貯蔵装置が設備された 場合とされない埸合の停電損失を比較した。その結 果, 〈3.3〉節では電力拧蔵装置の配置に関する幾つか の方針を明確にし，〈4.3〉節では，復旧時におりる䉓 力䝪蔵装置の停電損失減少效果を確認した。

なお，北大大型計算機センターHITAC M/200 H を利用した演算時間は，最適配置問題之最適負荷復旧 順序決定問題の最す複㒕な数值例で各々 178.3 秒,

1.95 秒であった。特に前者はオフラインでの評洒手 法であるととを考えれば，実用上問題はないと思われ る。

終りに, 一連の研究において御指導を賜る前北見工 業大学長 (現在, 道都大学長) 小池東一郎博士, 北海 道大学工学部 長谷川 淙教授に深謝申し上げます。 (昭和60年 1 月 23 日受付, 同60年 4 月 22 日再受付)

\section{文献}

(1) Y. Sekine: "Load Factor Improvement of Power System and its Evaluation", Research on Effective Utilization and Densification of Electric Energy, p. 127 (1983-10)

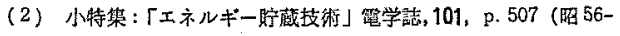
6)

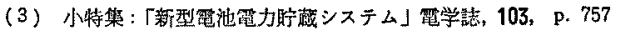
(明 58-8)

(4) 諸住・西谷・長谷川・藤原: 「雪力系統化おける分散形雷力

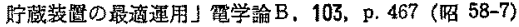

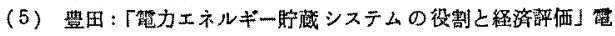
学諭 B, 104, p. 273 (绍 59-5)

(6) F.C. Shweppe: "Power System 2000 : Hierarchical control Strategies" IEEE Spectrum 15, 7, p. 42 (1978-7)

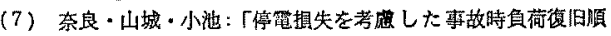
芧心决定方法」西学馀 B，101，p.77 (昭 56-2)

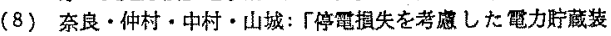

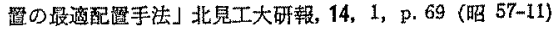

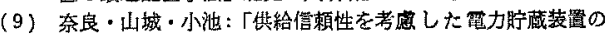

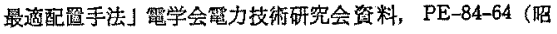
59-7)

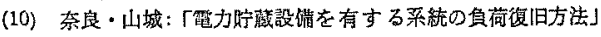
沼 59 電気闑倸学会北海道支部連大 151

(11) 闺根, 他：「電力系統工学」 p. 170 (昭 54-3) コロナ社

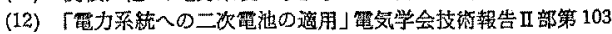
号, p. 14 (弨 55-10)

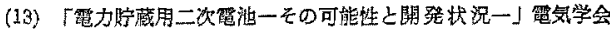

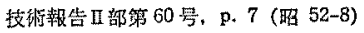

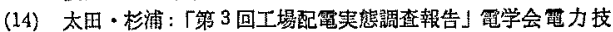
術研究会㾞料. ET-71-16 (昭 46-4)

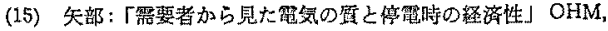
59, p. 57 (晒 47-4) 